\title{
BIOCHAR TO IMPROVE THE QUALITY AND PRODUCTIVITY OF SOILS
}

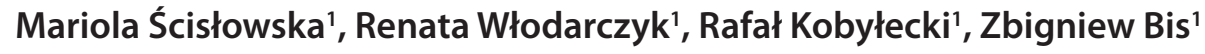 \\ 1 Department of Energy Engineering, Faculty of Environmental Engineering and Biotechnology, Częstochowa \\ University of Technology, Brzeźnicka 60 a, 42-200 Częstochowa, Poland, e-mail: m.scislowska@is.pcz.czest.pl
}

Received: 2015.03.02

Accepted: 2015.06.02

Published: 2015.07.01

\begin{abstract}
The paper presents the results of research focused on the investigations of the possibilities to use biochar to improve the quality and productivity of soils. Biochar is a material similar to the commonly known charcoal obtained from the thermolysis process (a process similar to dry distillation of wood). The structure and technical properties of biochar depend on the type of biomass which is produced and the thermal decomposition process conditions: process time, temperature and atmosphere. It was found that a positive effect of biochar on the soil properties is manifested through the improvement of soil fertility, better water retention, improvement of the cation exchange, and the regulation of the $\mathrm{pH}$. The biochar used in the present study was obtained by autothermal thermolysis of biomass at $300{ }^{\circ} \mathrm{C}$. Three types of biochars of different origin were used. The biochar samples were subjected to ultimate and proximate analysis, as well as structural and porosimetric investigations. The experimental research were also conducted on the experimental test field and gave a positive effect of the presence of biochar on soil quality and plant yield. Biochar introduced into soil allows for longterm storage of carbon. The introduction of biochar to soil has a positive effect on plant growth, higher dose resulted in an increase in biochar and plant mass.
\end{abstract}

Keywords: biomass, biochar, soil properties.

\section{INTRODUCTION}

$75 \%$ of the area of Poland is covered by dystric, brunic, luvic and albic soils, with only $<1 \%$ of total surface covered by very good soils i.e. chernozems [Skłodowski, Bielska, 2009]. It is necessary to fertilize poor soils in order to use them effectively. Soil quality is improved in Poland through liming (control of chemical reaction), enrichment of sorption complex, introduction of the organic substance (peat, brown coal, organic fertilizers) or through enrichment of loamy fraction (soil loaming, synthetic sorbents, natural modified sorbents), phytostabilization and synthetic fertilization [Karczewska, 2009]. Recently, particular attention was paid to opportunities of improvement of soil properties through the use of biochar. Such studies have been carried out both in Europe and all over the world [Hunt et al. 2010].

Previous studies have demonstrated that biochar in soil increases fertility through im- provement of cation exchange and opportunities for growth of microorganisms; it improves soil capability of absorbing water and makes it easier to control $\mathrm{pH}$ in soil. Studies carried out by Beesely and Nigussie [Nigussie, 2012] found that biochar added to poor and degraded soils might contribute to improvement of fertility and productivity of soils and help protect plants [Malińska, 2012]. Biochar has alcaline reaction $(\mathrm{pH}$ 7.0-7.8) and can be used for neutralization of acid soils, which account for $45 \%$ in Poland [Zarzycki 2007]. Biochar might also represent a catalyst to improve absorption of potassium ions, absorbed in certain ranges of soil $\mathrm{pH}$. Addition of biochar to soil might replenish and equalize carbon balance and contribute to carbon sequestration in soil [Gajić, 2011]. C to $\mathrm{N}$ ratio is important in soils as it reflects nitrogen availability for plants. Balance between the processes of immobilization and mineralization occurs when $\mathrm{C} / \mathrm{N}$ ratio in the decaying organic 
substance is $20-30 / 1$, whereas nitrogen content ranges from 1.2 to $1.8 \%$ [Kacprzak, 2007].

No specific studies have been carried out in Poland on the effect of addition of biochar on the improvement in medium-class soils (III-IV soil bonitation class), poor and very poor soils (V and VI class) and increase in vegetation mass in such soils [Kobyłecki, 2014]. The structure of biochar and its physical properties depend on the type of biomass it is made of and on thermolysis: process duration, temperature and atmosphere. Biochar is a material similar to the substance commonly known as charcoal, obtained through thermolysis (a process much similar to dry distillation of wood) of biomass of different origins [Kobyłecki et al. 2005; Kobyłecki, Bis 2006; Kobyłecki et al. 2008; Kobyłecki 2011, Bis 2012, Bis 2013]. With respect to the character of this study, the most important biochar parameters are chemical composition, specific surface area and porosity.

This paper presents the results of the study concerning the opportunities of the use of biochar to improve soil quality and productivity. Three types of biochar (of different origins) were used in the study. The samples were subjected to stuctural, porosimetry, technical and elemental analyses. Experiments were also carried out on an experimental test field.

\section{MATERIAL AND METHODS}

Biochars obtained in the process of autothermic biomass thermolysis at the temperature of $300^{\circ} \mathrm{C}$ were used in order to analyse the opportunities to use biochar to improve soil quality. The processes of biochar production in a reactor consist in ensuring pressure and flow conditions in order to obtain maximum rate of heating the fragmented biomass to the temperature of over $300{ }^{\circ} \mathrm{C}$ [Kobyłecki et al. 2005; Kobyłecki, Bis 2006; Kobyłecki et al. 2008; Kobyłecki 2011]. Three types of biochar obtained from different biomass were used in the study: pine tree biomass (Biochar 1), willow biomass (Biochar 2) and miscanthus biomass (Biochar 3).

Technical analysis of biochar was made according to Polish Standard PN-G-04560:1998P. The analysis of the content of carbon (C), hydrogen $(\mathrm{H})$, nitrogen $(\mathrm{N})$ and sulphur $(\mathrm{S})$ was carried out in elemental analyzer (LECO). Heat of combustion was determined using IKA Basic C
2000 calorimeter using the isoperibolic method. Philips XL30/LaB6 scanning microscope was used for structural analysis of biochar. Porosity of biochar was determined using PoreMaster 33 mercury porosimeter with Quantachrome Instruments software.

\section{RESULTS AND DISCUSSION}

Technical analysis showed that Biochar 2 had the lowest content of ash whereas biochar 2 had the lowest content of volatile fractions and water. Elemental analysis showed the highest coal content in biochar 3 (ca. 82\%), with the lowest content observed in biochar 2 (ca. 72\%). All three biochars are characterized by high calorific value (over $27 \mathrm{~kJ} / \mathrm{kg}$ ). From the standpoint of the use of biochar, the best properties are observed for Biochar 3 , characterized by high content of carbon and low content of volatile fraction.

Table 1 presents the results of technical analysis (e.g. content of water, ash and volatile fractions), elemental analysis (content of carbon, nitrogen, hydrogen and sulphur) and calorific value of three different biochars.

In order to evaluate the effect of open structure of biochar on improvement in soil quality, structural and porosity analyses were carried out for Biochar 3.

According to a classification introduced by IUPAC (International Union of Pure and Applied Chemistry), there are three basic classes of pores: micropores - with diameter of $<0.002$ $\mu \mathrm{m}$; mesopores, with diameter of $0.002-0.050$ $\mu \mathrm{m}$; macropores, with diameter of $>0.050 \mu \mathrm{m}$. Micropores and mesopores determine the size of internal surface and are essential for adsorption processes. Macropores perform the role of routes of transport, providing access to the pores of smaller sizes. With respect to the method of the use of biochar, the presence of macropores will substantially contribute to improved water balance in soil.

Figure 2 illustrates the structure of biochar obtained during carbonization at the temperature of over $300{ }^{\circ} \mathrm{C}$. Biochar shows a fibrous structure with open pores with diameter of ca. $50 \mu \mathrm{m}$. Porosimetric analysis revealed mean pore size as presented in Figure 1A.

Open porosity, specific surface and biochar density were determined based on porosimetry examinations (Table 2). As results from the data 
Table 1. Proximate and elemental ultimate analysis of biochar sample (dry)

\begin{tabular}{|l|c|c|c|c|c|c|c|c|c|c|}
\hline Type of biochar & $\begin{array}{c}\mathrm{W}_{\mathrm{T}} \\
{[\%]}\end{array}$ & $\begin{array}{c}\mathrm{VM}^{\mathrm{d}} \\
{[\%]}\end{array}$ & $\begin{array}{c}\mathrm{A}^{\mathrm{d} 815} \\
{[\%]}\end{array}$ & $\begin{array}{c}\mathrm{FC}^{\mathrm{d}} \\
{[\%]}\end{array}$ & $\begin{array}{c}\mathrm{C}^{\mathrm{d}} \\
{[-]}\end{array}$ & $\begin{array}{c}\mathrm{H}^{\mathrm{d}} \\
{[-]}\end{array}$ & $\begin{array}{c}\mathrm{N}^{\mathrm{d}} \\
{[-]}\end{array}$ & $\begin{array}{c}\mathrm{S}^{\mathrm{d}} \\
{[-]}\end{array}$ & $\begin{array}{c}W^{\mathrm{d}} \\
{[\mathrm{kJ} / \mathrm{kg}]}\end{array}$ & $\begin{array}{c}W^{d} \\
{[\mathrm{~kJ} / \mathrm{kg}]}\end{array}$ \\
\hline Biochar 1 & 7.4 & 20.0 & 5.2 & 74.80 & 77.40 & 3.00 & 0.80 & 0.00 & 29013 & 28153 \\
\hline Biochar 2 & 12.4 & 31.1 & 4.9 & 64.00 & 72.30 & 4.50 & 0.50 & 0.00 & 27501 & 26179 \\
\hline Biochar 3 & 1.7 & 16.5 & 5.5 & 78.00 & 82.20 & 3.00 & 0.70 & 0.00 & 28743 & 28026 \\
\hline
\end{tabular}

Comments: $\mathrm{W}_{\mathrm{T}}$ - total water, $\mathrm{VM}$ - total volatile fractions, $\mathrm{A}$ - ash content, $\mathrm{FC}$ - fixed carbon, $\mathrm{Wg}$ - combustion heat, $\mathrm{Wd}$ - calorific value.

a)

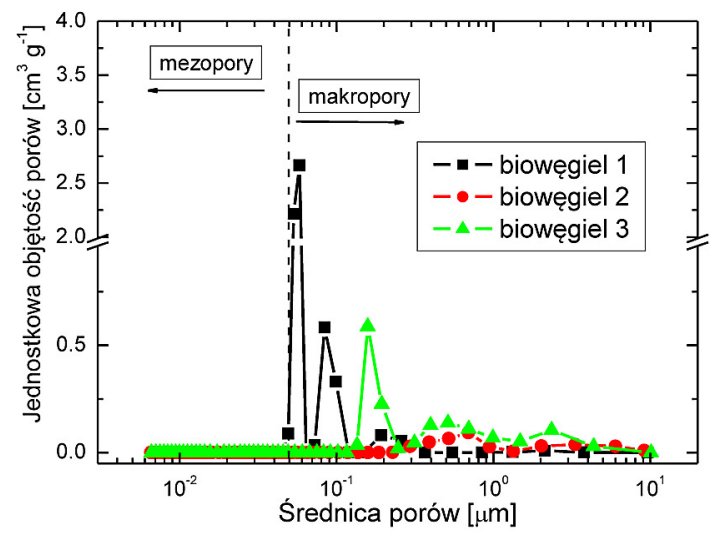

b)

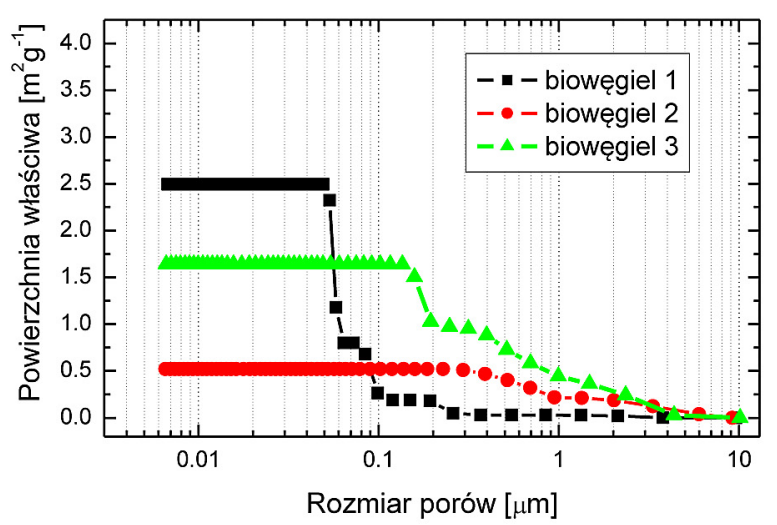

Figure 1. Pore size distribution (a) and surface areas (b) of biochars tested

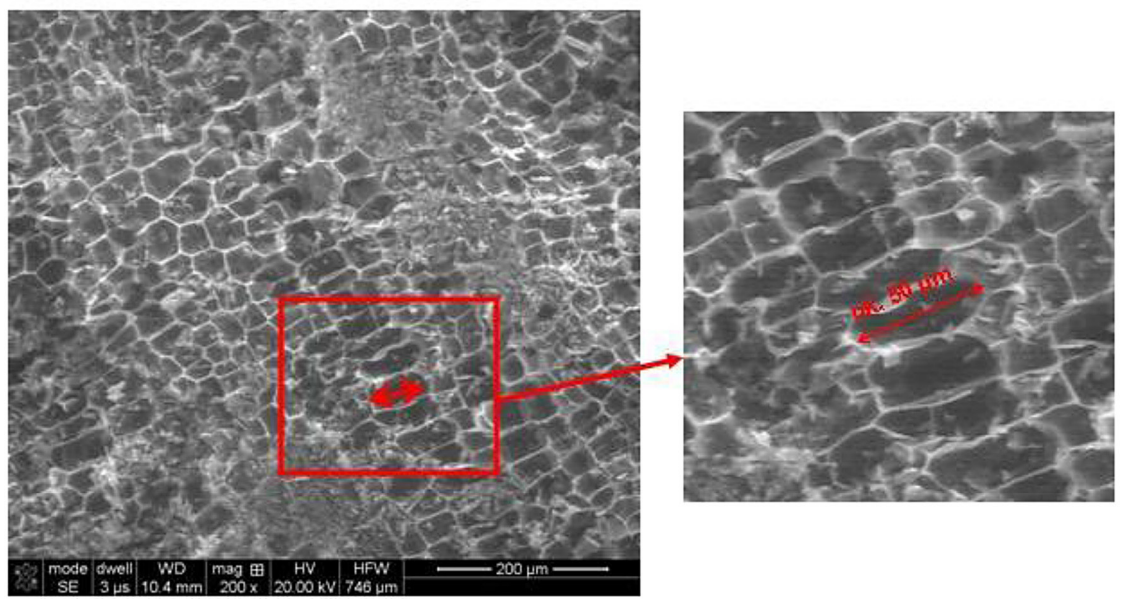

Figure 2. Microstructure of biochar obtained from pine wood

Table 2. The results estimated based on porosimetric analysis

\begin{tabular}{|c|c|c|c|}
\hline Specification & $\begin{array}{c}\text { Open porosity } \\
{[\%]}\end{array}$ & $\begin{array}{c}\text { Specific } \\
\text { surface }\left[\mathrm{m}^{2} / \mathrm{g}\right]\end{array}$ & $\begin{array}{c}\text { Density } \\
{\left[\mathrm{g} / \mathrm{cm}^{3}\right]}\end{array}$ \\
\hline Biochar 1 & 4.02 & 2.49 & 0.59 \\
\hline Biochar 2 & 20.50 & 0.52 & 0.72 \\
\hline Biochar 3 & 27.68 & 1.64 & 0.71 \\
\hline
\end{tabular}

presented in Table 2, the highest specific surface was found for biochar 1 (see Figure 1). Furthermore, the highest value of open porosity is observed for Biochar $3(>27 \%)$. Considering the use of biochars in soil, high porosity is beneficial since it might contribute to improvement in water balance in soil and positively affect microelement availability in plants.

After the analysis of properties of biochar (elemental analysis and porosity), Biochar 3 was selected for test field experiments (from miscanthus biomass). This was caused by substantial content of carbon and high open porosity and specific surface of biochar.

Biochar was added to soil using three different doses $\left(3 \mathrm{~kg} / \mathrm{m}^{2}, 7.5 \mathrm{~kg} / \mathrm{m}^{2}, 10 \mathrm{~kg} / \mathrm{m}^{2}\right)$ and, on such test fields (with dimensions of $1 \times 1 \mathrm{~m}$ ) charlock and lupine were sown. Figure 3 presents a view of the experimental test field two 
06.07 .12
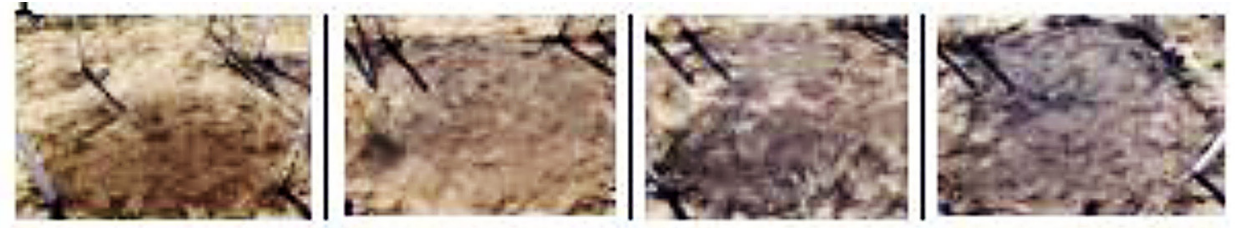

14.07 .12
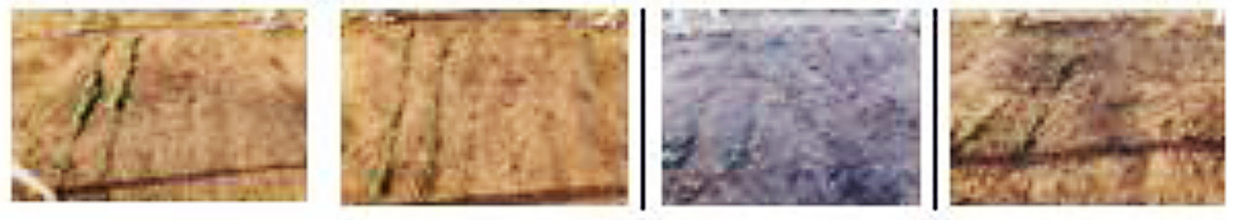

27.07 .12
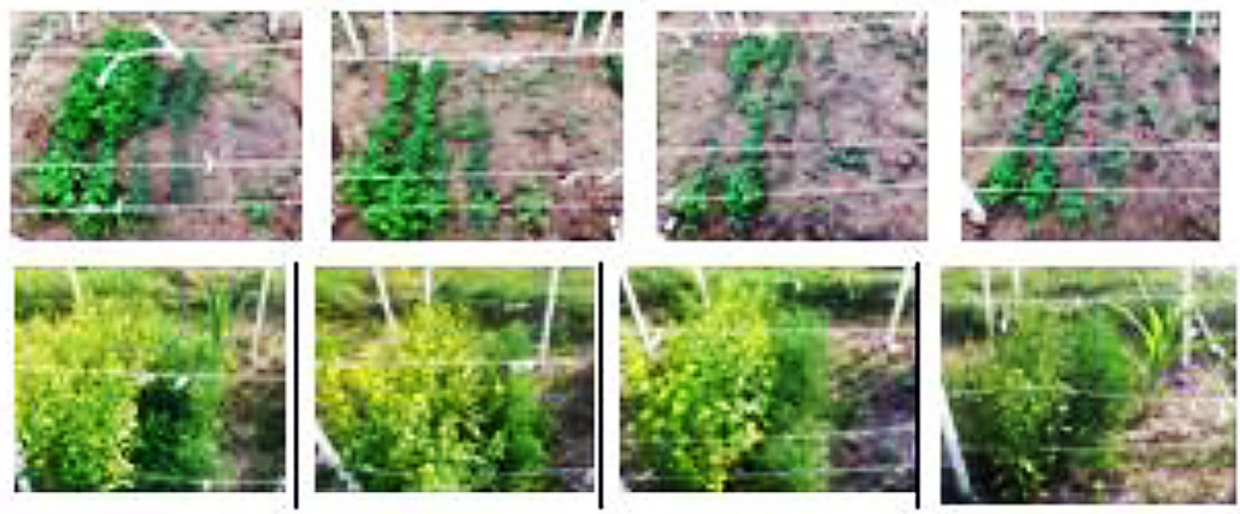

12.09 .12
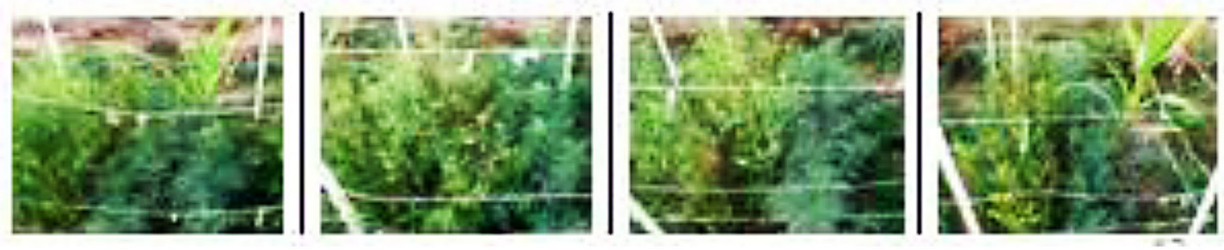

Figure 3. Plant growth vs. time in the experimental test field

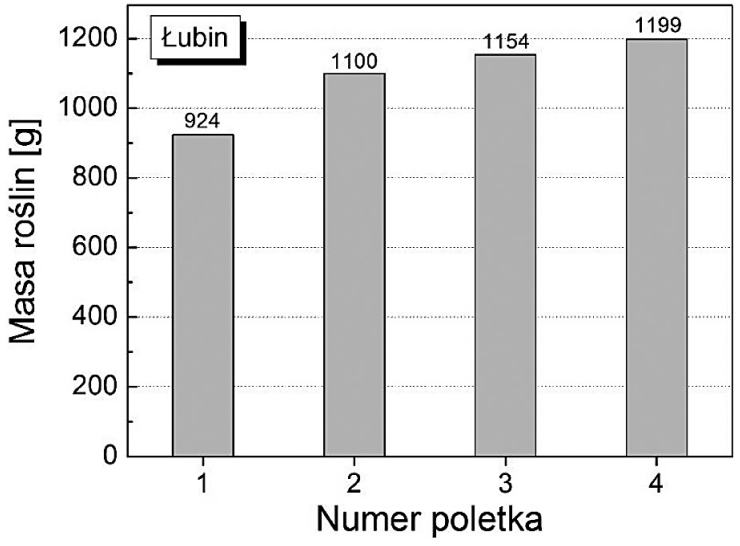

Figure 4. Weight of the lupine collected from the experimental test field

months after sowing. Figures 4 and 5 show the diagrams that illustrate the mass of plants (lupine in Figure 4 and charlock in Figure 5) depending on the biochar dose used. Figure 3 presents selected photographs showing the growth of plants in the experimental test field. It can be observed that addition of biochar af-

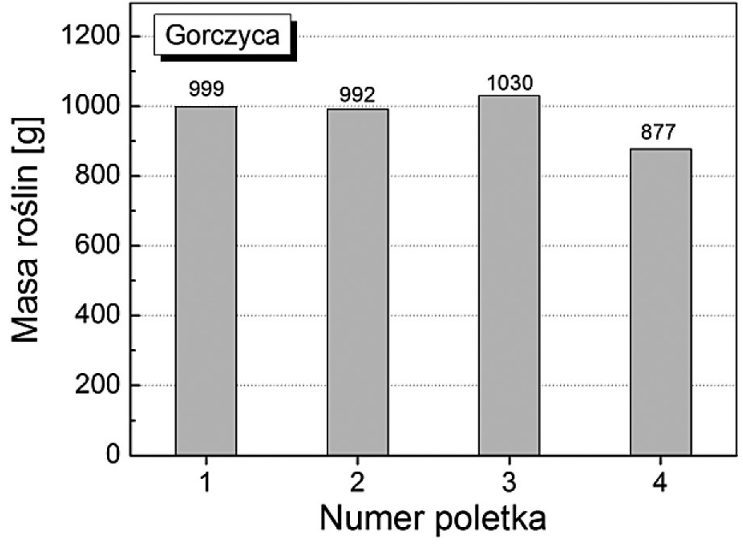

Figure 5. Weight of the charlock collected from the experimental test field

fects both the size of plants and the mass of crops. The greatest mass of lupine was found in the test field 4, whereas the greatest mass of charlock was harvested in the test field 3 . The authors are in the process of preparation of a more detailed study concerning the effect of biochar on soil properties. 


\section{CONCLUSIONS}

In conclusion, changes and effects caused by biochar in soil remain largely unknown. Although physicochemical properties of biochar and mechanism of its stabilization might be explained by long period of presence in soil, the effect of various factors on short- and long-term loss from soil has not been researched sufficiently yet. Also, little is known about the loss and transfer of biochar into the profile, moving to ground waters and transport mechanisms. The scientific research in this field is currently carried out by the authors.

The results presented in this study lead to the following conclusions:

1. Physicochemical and porosimetric properties of biochar depend mainly on biomass used for the production of biochar.

2. High porosity of biochars might contribute to improvement in water balance in soil and will positively affect microelement availability for plants.

3. Addition of biochar to soil positively affects growth of plants while greater dose of biochar caused a greater increase in plant mass.

\section{Acknowledgements}

This study was financed within statutory research BS/MN-404-301/13.

\section{REFERENCES}

1. Bis Z. 2013. Biochar - a return to teh past, a chance for the futer. Czysta Energia, 6, 28-31.

2. Bis Z. 2013. Is coal will be a child of Europe? Nowa Energia, 2(32), 4-10.

3. Gajić A., Koch H.J., Märländer B. 2011. HTC Biokohle als Bodenverbesserer - Erste Ergebnisse aus einem Feldversuch mit Zuckerrüben. Sugar Industry/Zuckerindustrie, 12, 791.

4. Hunt J., DuPonte M., Sato D., Kawabata A. 2010. The basics of biochar: a natural soil admendment. University of Hawaii at Manoa, Saoil and Crop Management, 12.
5. Kacprzak M. 2007. Wspomaganie procesów remediacji gleb zdegradowanych. Monografia nr 128, Czestochowa University of Technology, 1-12.

6. Karczewska A. 2009. Metody rekultywacji gleb zdegradowanych i zdewastowanych.

7. Kobyłecki R., Bis Z., Nowak W. 2005. Zwaloryzowana biomasa i paliwa alternatywne - wartościowe surowce dla czystej konwersji energii. Ekologia, Energie Odnawialne, Ciepłownictwo w Polsce i na Świecie, 3/4, 44-46.

8. Kobyłecki R., Bis Z. 2006. Biocarbon - efektywna konwersja energii ze źródeł odnawialnych. Energetyka, 57-58.

9. Kobyłecki R., Tchórz J., Bis Z. 2008. Densification of biomass energy for large scale co-combustion.Proc. of the $9^{\text {th }}$ International Conference on Circulating Fluidized Beds CFB-9 in conjunction with $4^{\text {th }}$ Int. VGB Workshop 13-16 May 2008, Hamburg.

10. Kobyłecki R. 2011. Obróbka termiczna biomasy. Czysta Energia, 6 (118), 46-47.

11. Kobyłecki R. 2014. Środowiskowe aspekty termolizy biomasy, wyd. Politechniki Częstochowkiej, seria Monografie, nr 290, Częstochowa.

12. Malińska K. 2012. Biowęgiel odpowiedzią na aktualne problemy ochrony środowiska. Inżynieria i Ochrona Środowiska, 15 (4), 387-403.

13. Nigussie A. Kissi E., Misganaw M., Ambaw G. 2012. Effect of biochor application on soil properties and nutriend uptake of lettuces (lactuca sativa) grown in chromium polluted soils. AmericanEurasian Journal of Agricultural and Enviromental Sciences, 12 (3).

14. Polska Norma PN-G-04560:1998P. Paliwa stałe oznaczenie zawartości wilgoci, części lotnych oraz popiołu analizatorem automatycznym.

15. Skłodowski P., Bielska A. 2009. Właściwości i urodzajność gleb Polski - podstawą kształtowania relacji rolno-środowiskowych. Woda-Środowisko-Obszary Wiejskie, 9 (4).

16. Ścisłowska M., Kobyłecki R., Bis Z. 2014. Biowęgiel jako dodatek do gleb. materiały Konferencji Naukowej "Ocena gleb użytkowanych rolniczo", Puławy 2014.

17. www.iupac.org, Sept 2014

18. Zarzycki R. Imbierowicz M., Stelmachowski M. 2007. Wprowadzenie do inżynierii i ochrony środowiska. Wyd. Naukowo-Techniczne, Warszawa. 